\title{
Ground subsidence in plains around Tehran: site survey, records compilation and analysis
}

\author{
Arash Pirouzi $^{*}$ (D) and Abolfazl Eslami ${ }^{2}$
}

*Correspondence:
apirouzi@umass.edu
${ }^{1}$ Department of Civil
and Environmental
Engineering, University
of Massachusetts, Amherst,
USA
Full list of author information
is available at the end of the
article

*Correspondence: apirouzi@umass.edu sachusetts, Amherst,

Full list of author information article

\begin{abstract}
Ground subsidence has been occurring in the southern areas of Tehran in the former 25 years. This phenomenon influences a $525 \mathrm{~km}^{2}$ area with a maximum measured value of $2530 \mathrm{~mm}$. Subsidence rate varies in different locations, and has a maximum rate of $360 \mathrm{~mm} /$ year in some areas. Existence of a thick layer of clay makes this region more susceptible to subsidence. Moreover, Tehran has been experiencing drought through these years which has resulted in decrease of groundwater level. This paper concentrates on variations of ground surface level in Tehran and Shahriar plains during 1992-2010, and studies its relationship with groundwater elevation changes in this period. Changes of ground and groundwater level are modeled via ArcGIS for several different time intervals. Current study reveals that in some locations, other factors including subsurface erosion, presence of old aqueducts, drainage of organic soils, and soil removal are more troublesome compared to groundwater elevation drawdown. In addition, site investigation is performed to study the occurrence of ground collapses, regional settlements, cracks in roads and buildings, and well-casing protrusion.
\end{abstract}

Keywords: Ground subsidence, Groundwater extraction, Tehran plain, Shahriar plain, Clay deposits, ArcGIS

\section{Introduction}

The term ground subsidence can be described as gradual or sudden downward displacement of ground surface due to consolidation of underground materials. Over-extraction of groundwater is the most common source of ground subsidence, but it can also happen under multiple other natural or man-made events (e.g. mining, dissolution of minerals, etc.). Fang and Daniels [9], define subsidence, in the broadest term, as the deformation or settlement of soil mass in any direction caused by different external loading, internal stress, and unbalanced environmental factors.

Land subsidence might result in different problems containing damages to linear structures, well casing failures, reduction or elimination of groundwater storages, desertification, flooding, deluging and sinkholes [21, 25]. Earth fissures are another consequence of subsidence that can be tens of meters deep and several hundred meters long. In general, earth fissures are more likely to happen in places with cemented upper layers [3]. Moreover, Subsidence is a costly phenomenon. In 1991, the annual costs of 
subsidence associated with flooding and structural damage in the United States were estimated to be more than $\$ 125$ million. In addition, Environmental costs like reduction of water storage cannot be calculated [11].

Land subsidence has been reported in many places including over 150 major cities worldwide [12]. Mexico City has experienced subsidence with a maximum rate of $30 \mathrm{~cm} /$ year due to excessive groundwater withdrawal $[5,19] .30,340$ square $\mathrm{km}$ of land in Southern Yangtse Delta, China is under subsidence. Over extraction of groundwater has caused subsidence of up to $3 \mathrm{~m}$ and 25 earth fissures [28]. Wairakei, New Zealand has suffered the most well-known reported case of subsidence caused by excessive extraction of geothermal energy and subsequent reduction of groundwater, leading to groundsurface settlements as large as $15 \mathrm{~m}$ [2]. Different plains in Iran have also experienced land subsidence. There are numerous reports of subsidence mostly resulting from overextraction of groundwater $[15,17,18,20]$.

Information regarding subsidence record, geology, water table, and geotechnical characteristics is crucial for subsidence investigations. Often this information is not available which is problematic for modeling processes. Except for some heavily studied sites, subsidence data is not sufficient because extensometer installation is expensive. Even when extensometer are available, there is not enough long term data to calibrate models [4].

Measurements of ground surface elevation in different locations of Tehran since 1992 show the quick development of subsidence [21]. High costs of subsidence in Tehran with more than 12 million population urges studying this incident. This article focuses on land subsidence occurred in Tehran and Shahriar plains during 1992-2010 employing accessible geological, geotechnical, ground surface elevation and water elevation data. The area of study is shown in Fig. 1.

\section{Causes of land subsidence}

Various phenomena such as underground fluid withdrawal, occurrence of sinkholes, drainage of organic soils, tectonic, mining, high thickness of young alluvium, tree roots, and subsurface flow can lead to subsidence [8]. Excessive extraction of groundwater is known to be the main cause of subsidence in most case. Subsidence have directly affected $44,000 \mathrm{~km}^{2}$ land in 45 different stated in the United States, among which more than 80 percent is caused by groundwater withdrawal [11]. In Iran, groundwater is the main source of water in many places because of the arid to semiarid climate. In addition, old and inefficient farming methods generate higher need to groundwater. These results in heavy extraction of groundwater and consequently water-level dropdown. Groundwater removal creates decrease in pore water pressure and increase in effective stress. This increase in effective stress causes compaction and subsidence. Groundwater removal in clayey material results in time rate settlement which continues long after pumping is stopped [3]. Houston has experienced subsidence under excessive withdrawal of fluids [10]. Extraction of oil, gas, water, and sand in Goose Creek initially generated the settlement [22]. Until 1979, over 82,000 $\mathrm{km}^{2}$ land experienced above $300 \mathrm{~cm}$ subsidence, leading to a relative rise in the sea-level, and a corresponding increase in flood magnitude and recurrence [13]. Ground subsidence in San Joaquin Valley is another subsidence case of subsidence due to excessive withdrawal of pore fluids. Massive groundwater pumping caused decomposition of carbon in organic soils and compaction of aquifer 


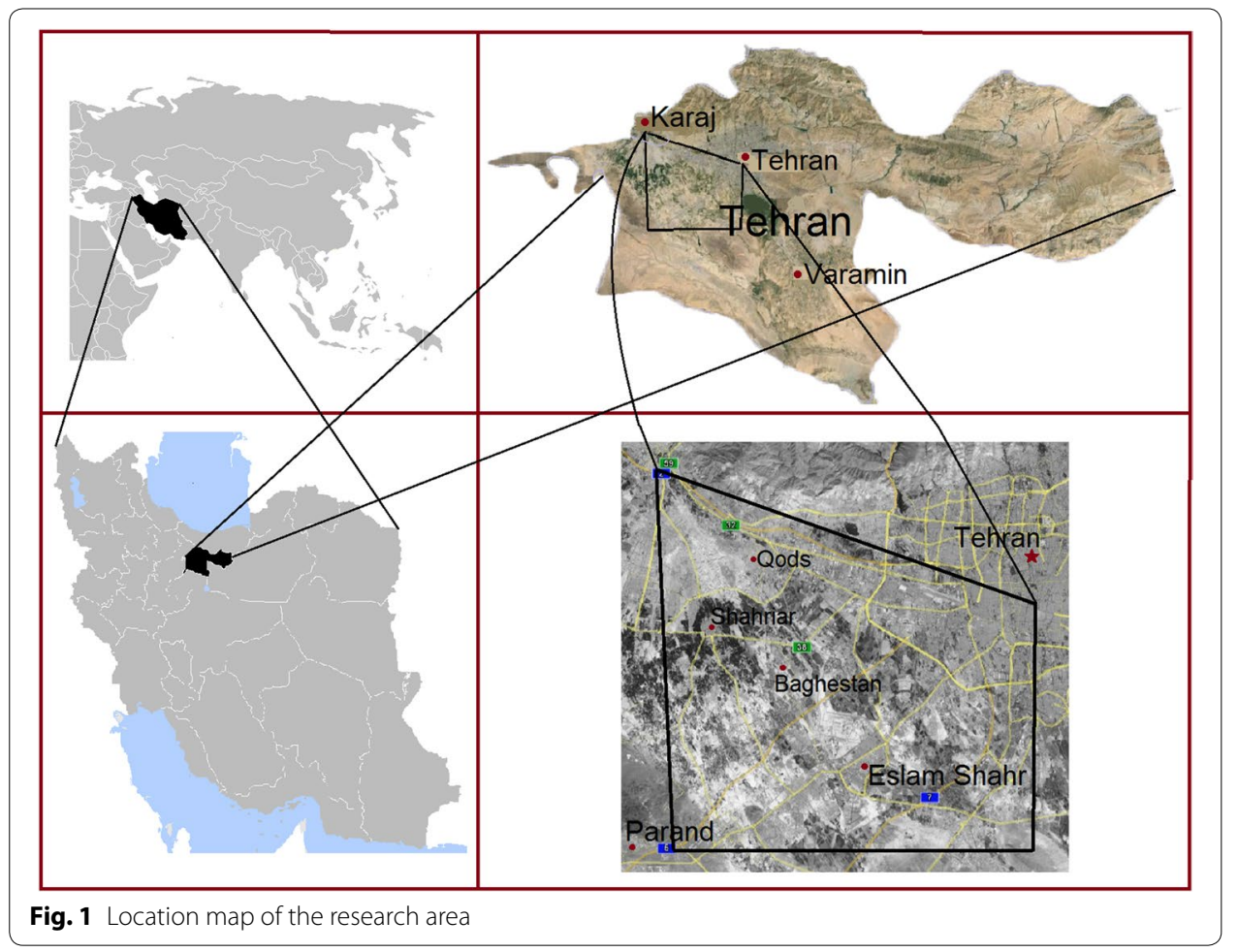

system [7]. Subsidence measurements as high as $9 \mathrm{~m}$ were reported from 1925 to 1977 in the delta [11].

Land subsidence is a regional phenomenon which makes it difficult to distinguish the affected areas. In the absence of subsidence indications including well protrusion and casing failures, it is almost impossible to recognize occurrence of subsidence in absence of periodic ground-surface level measurements are conducted using surveying, extensometers, InSAR methods, etc. [11].

Ground subsidence has occurred in several plains in Iran. Iran is geographically located in an arid region with limited surface water where annual precipitation hardly reaches $250 \mathrm{~mm}$. Groundwater is a substantial source of providing drinking and agricultural water in Iran which has resulted in excessive groundwater withdrawal and ground subsidence. In Rafsanjan Plain, subsidence rate is 10 percent of water-level decrease rate [18]. Subsidence of $900 \mathrm{~mm}$ as a result of a $15 \mathrm{~m}$ drop in Mashhad Plain [16], and subsidence of $200 \mathrm{~m}$ in Hashtgerd are some of the examples in Iran [6]. Southern Tehran has been experiencing subsidence with an increasing rate. Shemshaki et al. [26] reported that during 1995-2003, maximum subsidence of $1710 \mathrm{~mm}$ occurred in Tehran. They also noted that from January 2004 to May 2005 subsidence was also taking place rapidly in Karaj and Jajrood. Blourchi [1] introduced the results of a recent study, introducing a maximum annual subsidence of $360 \mathrm{~mm} /$ year in Tehran. All the performed studies suggest excessive groundwater withdrawal as the cause of subsidence. Mahmoudpour et al. [14] reported that groundwater level decreased $11.65 \mathrm{~m}$ from 1984 to 2012. 


\section{Case study: subsidence in Tehran}

Wide range of data including geological condition, geotechnical characteristics, climate pattern, and hydrological and hydrogeological situation is required for investigating ground subsidence.

Tehran, from north, is limited to Alborz Mountains and it reaches Tehran plane from south. Northern parts with altitude up to $1800 \mathrm{~m}$ have Mediterranean climate, while in southern parts altitude is up to $950 \mathrm{~m}$ and climate is semi-arid. Mean annual precipitation is $256.56 \mathrm{~mm}$. Geological condition in Tehran has been studied by several researchers in the past. First, Rieben [23, 24] divided Tehran into 4 alluvium categories, called A, B, C, and D (A being the oldest and D being the youngest). Many researchers later used this classification as the basic for their studies. Southwestern area of Tehran is covered with C (fine-grained and granular soil) and D (fine-grained soil) alluvium. Tehran Plain comprises both southwestern area of Tehran and southern suburbs; however, in this study Tehran Plain refers only to the area outside the city.

Aquifer system is multi-layered and consists of three aquifers. The aquifer system is recharged by various rivers, among which Karaj River had the largest impact. However, after construction of Karaj Dam, the aquifer has only been partially recharged by river in flooding season. Kan River, which is perennial and recharges both Tehran and Shahriar Plain, now has the largest part in recharge processes. Sewage is another source of aquifer recharge which has also been reduced by large due to the construction of sewerage system. Furthermore, increase in population and demand for housing resulted in destroying parks and landscapes to build new apartments. All the above created a city mainly covered with apartments, streets, and concrete tranches not allowing water to penetrate into the soil and recharge the aquifer.

In general, transmissivity has a reducing pattern from north to south of the region. High alluvium thickness and larger soil particles in the northers parts results in higher transmissivity, up to $3000 \mathrm{~m}^{2}$ compare to $500 \mathrm{~m}^{2}$ [26]. Groundwater level has a similar trend and reduces from north to south. Excessive water drawdown, which will be explained later, has led to this gradient.

\section{Benchmarks}

As indicated, long term ground surface elevation data is essential in subsidence modeling. Ground surface measurement of 96 benchmarks in the area, collected periodically from 1992 to 2010 by the National Cartographic Center, is utilized in this study. Figure 2 shows the location of the benchmarks used in this study. Of 96 utilized benchmarks, global coordinates of 78 benchmarks are available. These five series of benchmarks (HSHT, HQHS, AY, HTHX and AXAY series) are shown using colored dots. Exact location of the remaining 18 benchmarks (HQSB series) is not available, but it is known that they are located along the red line (Fig. 2) in approximately $700 \mathrm{~m}$ intervals.

HSHT, HQHS and HTHX benchmarks are located in southwestern and southern area of Tehran city and are representative of subsidence in the city. AY benchmarks represent ground elevation changes in Tehran plain and parts of Shahriar plain. In addition, AXAY benchmarks are located in Shahriar plain, starting from south of Karaj. 


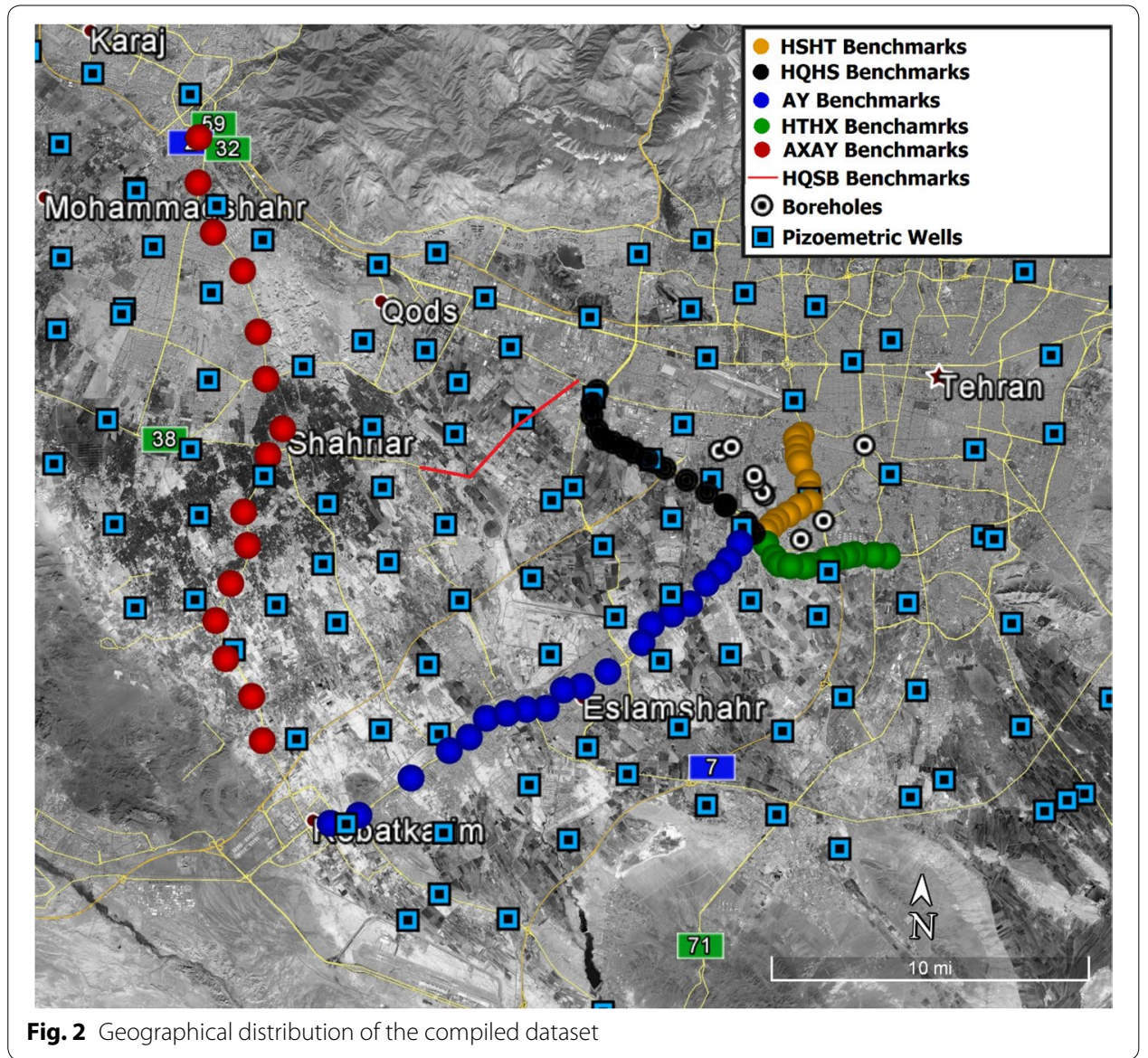

\section{Boreholes}

The database is compiled of laboratory test results on samples from more than 40 boreholes of mostly $30 \mathrm{~m}$ deep or shallower. Boreholes are largely located in north eastern parts of the area (i.e. south west of Tehran) as the land in other locations is mainly agricultural, and not many deep geotechnical investigations have been conducted there. Location of the boreholes is presented in Fig. 2 as well as the ArcGIS plots introduced later. Location of the boreholes without global coordinates is not shown in ArcGIS plots.

\section{Piezometric wells}

Ground subsidence is known to have direct relationship with groundwater level changes. Groundwater elevation data from 146 piezometric wells is collected from Tehran Regional Water Authority database. The wells are illustrated in Fig. 2 by blue marks. It is apparent from the figure that piezometric wells are appropriately scattered within the plains. Groundwater level measurements were conducted manually every month during 2002-2011 period. The average annual levels are used in this research.

\section{Aqueducts}

As mentioned earlier, collapse and subsurface erosion caused by existence of underground aqueducts could also result in ground subsidence. Therefore, a comprehensive 
set of Tehran aqueduct maps prepared by TDDMO (Tehran Disaster Mitigation and Management Organization) [27] is used in this study. Figure 3 illustrates TDMMO map in Moalem Square, located near the northern HSHT benchmarks.

"Qanat" is an old aqueduct system which used to be the largest water supplier in Tehran. Growth in population and consequently the need to more water resulted in exponential increase in the number of water wells in the city and a large decrease in the discharge of aqueducts and therefore abandonment of many aqueducts. In 1966, there were more than 522 dischargeable qanats in the area, which declined to 76 by 2003 . There are $100 \mathrm{~km}$ of aqueducts under Tehran, some of which are over $130 \mathrm{~m}$ deep. qanat shafts are commonly in 15 to $20 \mathrm{~m}$ intervals, and are $0.8-0.9 \mathrm{~m}$ in diameter. Dimension of channel profiles is mostly 1.2 by $0.9 \mathrm{~m}$, with lengths up to $18 \mathrm{~km}$.

\section{Data analysis}

\section{Ground subsidence}

Ground-surface level changes are modeled by employing ArcGIS. Raster model is used over vector model as it provides better results in modeling problems containing elevation changes in large areas.

Ground subsidence is plotted for 1992-2001, 2001-2003, 2003-2004, 2004-2005, 2001-2005, and 2001-2010 intervals. Figures 4, 5 illustrate ground subsidence occurred in 1992-2001 and 2001-2010, respectively. AXAY Benchmarks were not measured in 2001, so Fig. 4 is limited to Tehran Plain, while Fig. 5 exhibits subsidence in all the studied area. Data from benchmarks without exact global coordinates (HQSB) is not used in ArcGIS maps. In the provided maps, downward displacements are represented as positive.

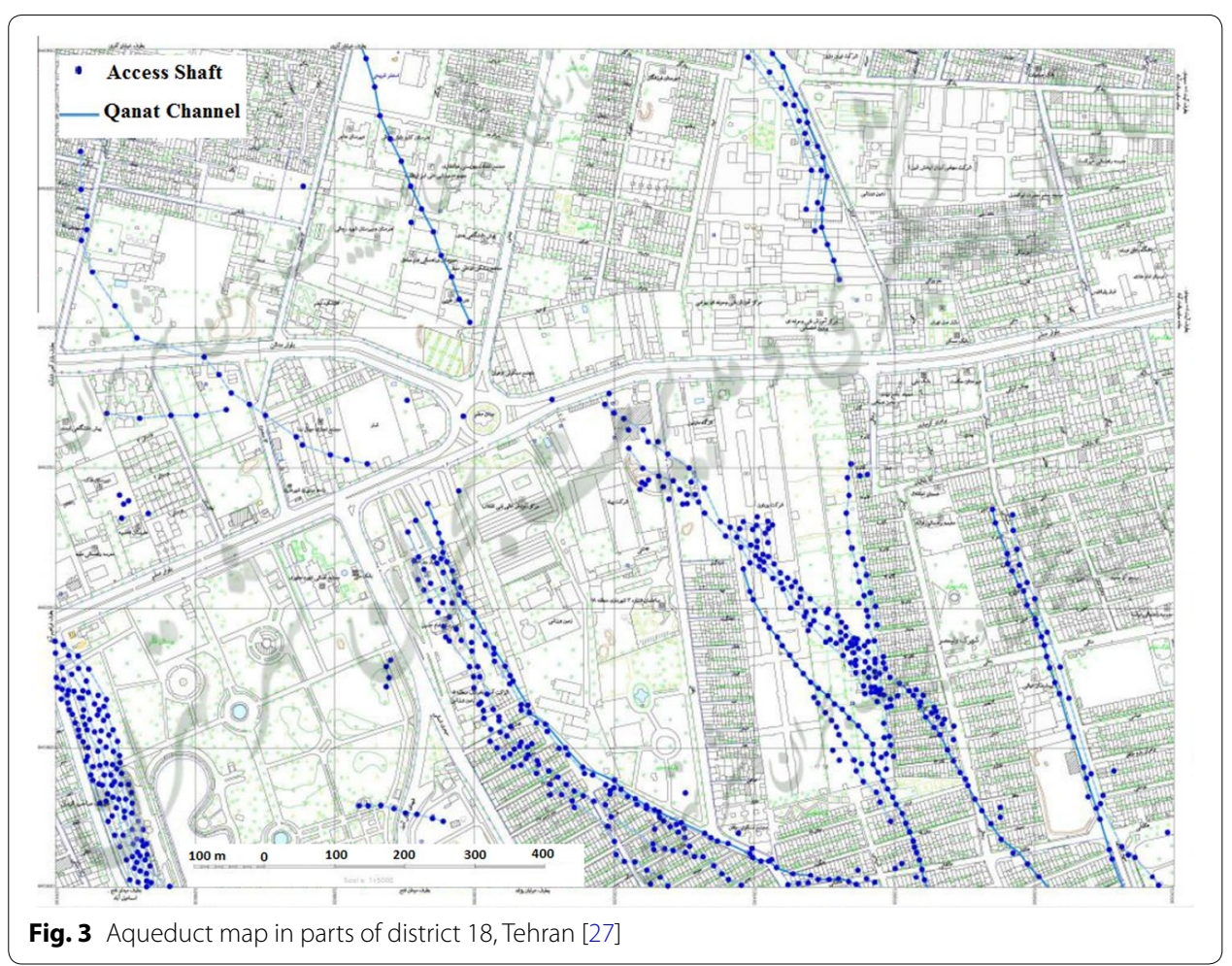



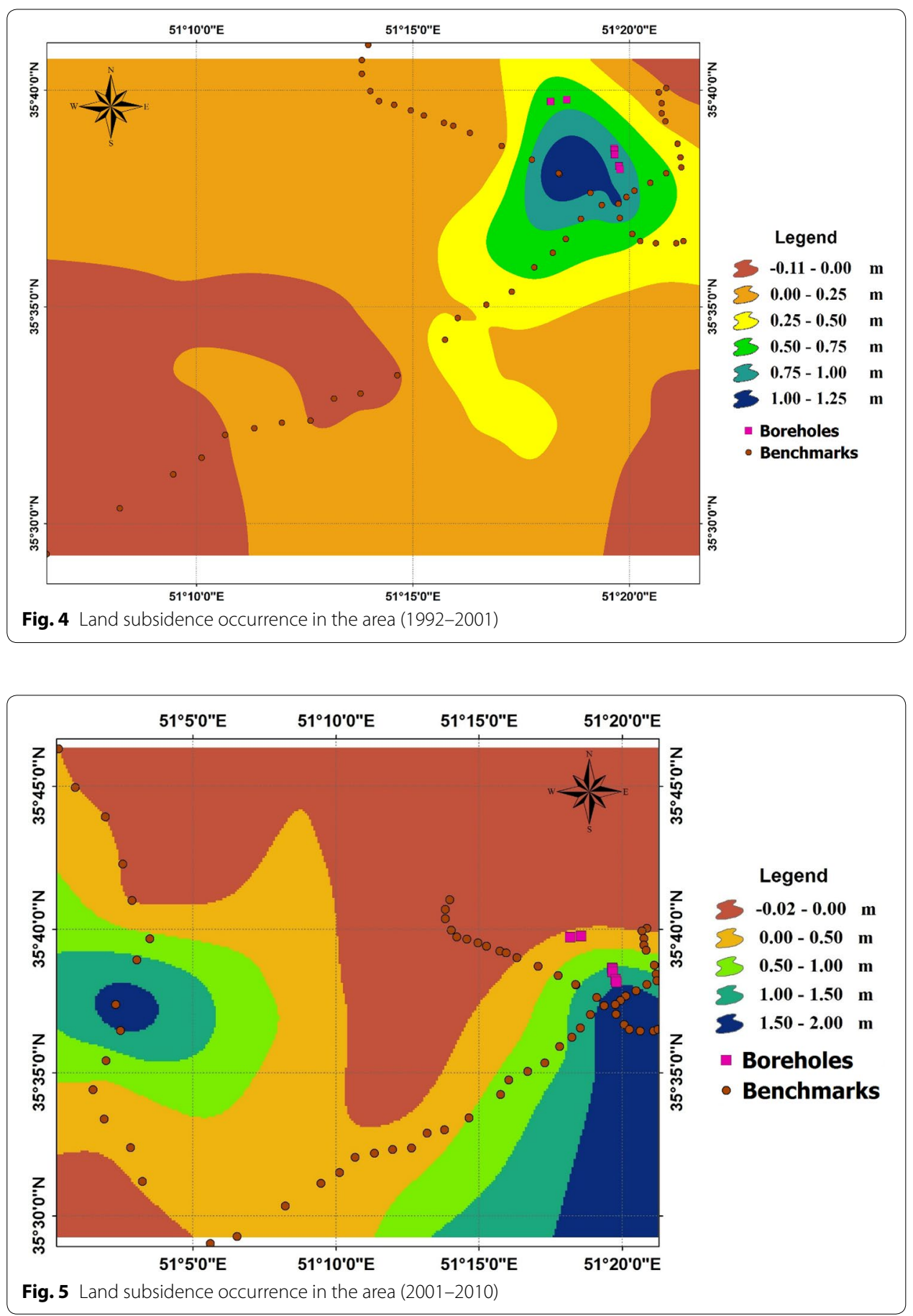

These maps verify the occurrence of subsidence in the studied area and only a few of them are presented here to show the trends. As shown in Fig. 4, the maximum subsidence from 1992 to 2001 is less than 1.25, measured in Yaft Abad (i.e. neighborhood located northwest of HQHS and HSHT crossing). For 2001-2003, the investigations were limited to southwest of Tehran due to lack of ground elevation measurements in other sections. Generated maps indicate rapid subsidence of up to $1.5 \mathrm{~m}$ in some 
locations on HTHX in this period. However, considering all the ground elevation measurements reported through different years, this measurement is not consistent with the general trend and appears to be inaccurate. Yet, subsidence of around $500 \mathrm{~mm}(250 \mathrm{~mm} /$ year) was recorded in several locations. In 2003-2004, measurements show that maximum subsidence rate decreases to $200 \mathrm{~mm}$ /year (Fig. 6). The data for this period is also limited to Tehran. Figure 7 shows the subsidence pattern during 2004-2005, maximum subsidence was measured around HQHS benchmarks with a rate $220 \mathrm{~mm} / \mathrm{year}$. In conclusion, for 1992-2005, maximum subsidence of $2050 \mathrm{~mm}$ was measured at the same place with maximum subsidence during 1992-2001 (i.e. Yaft Abad). Figure 8 illustrates subsidence in this period.

Figure 5 shows the subsidence occurred in 2001-2010. Ground elevation data for most of the benchmarks in Tehran, including places with maximum rate of settlement from 1992 to 2005 (i.e. Yaft Abad), is not available for 2010 which causes the subsidence
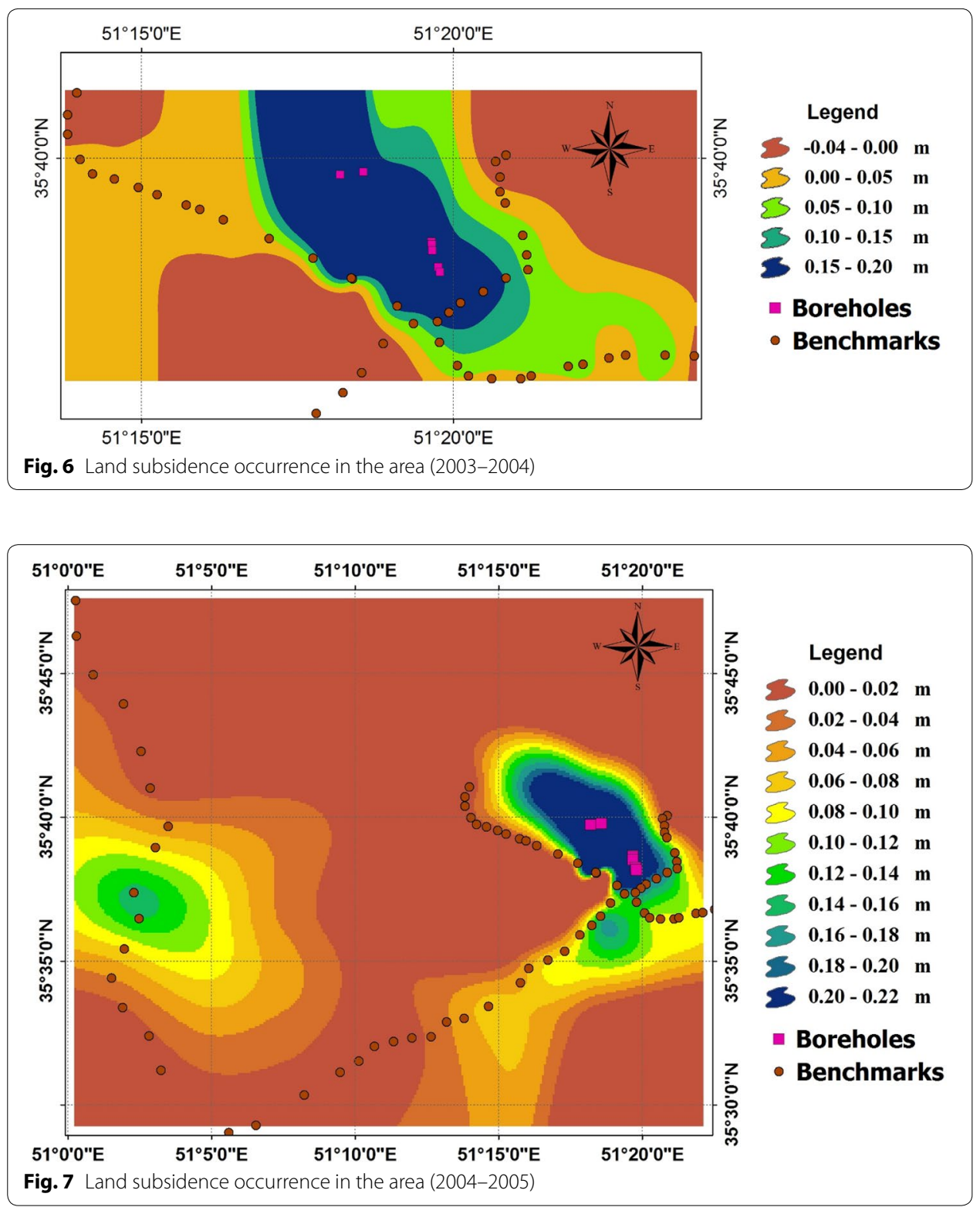


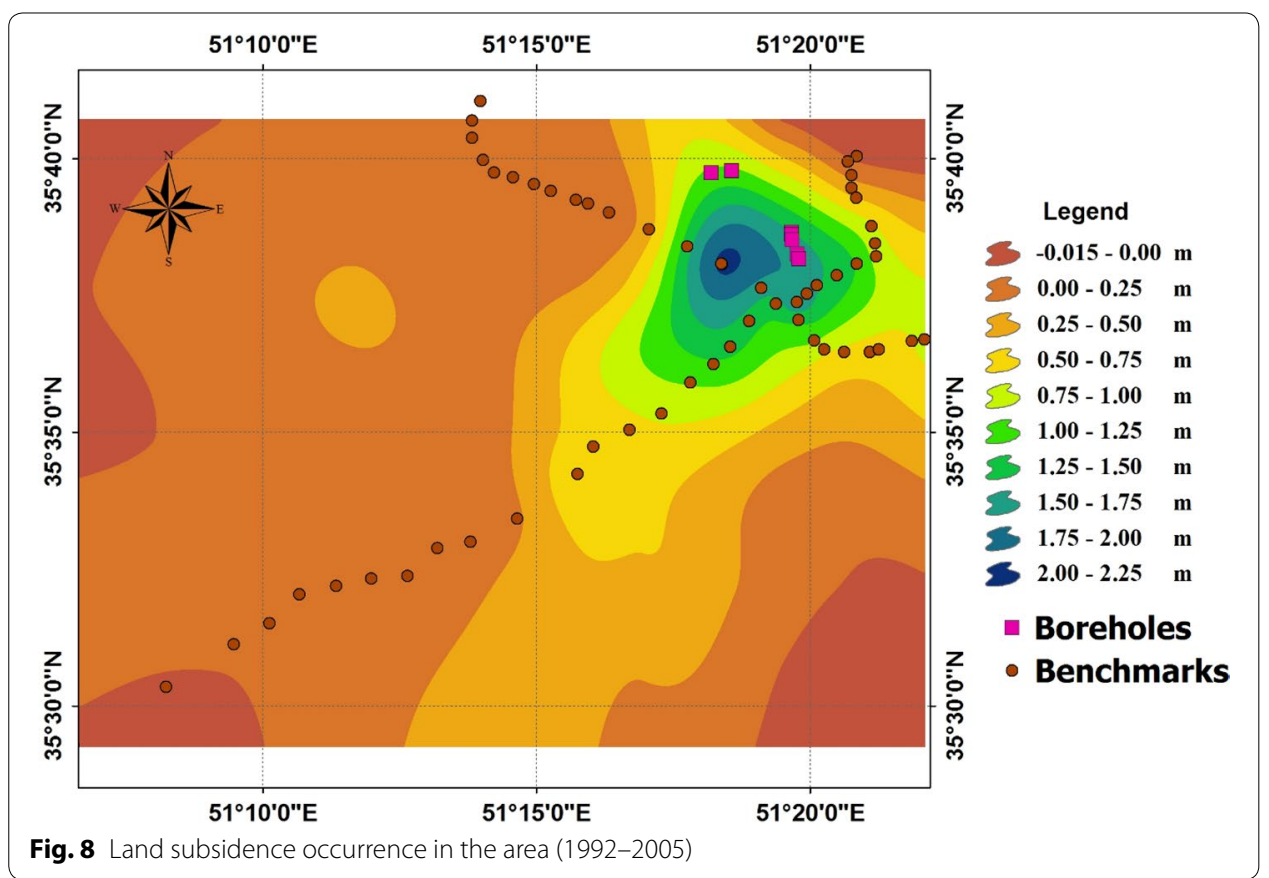

for south of Tehran in this figure to be lower than the real values. However, looking at the other maps for the years following 2001, including 2001-2005 where most of the benchmarks were surveyed, the dominating subsidence trend is comparable to that of 1992-2001. Subsidence rate in the same period was increasing in south of Tehran Plain. During 2001-2010, maximum measured subsidence was $2000 \mathrm{~mm}(220 \mathrm{~mm} /$ year). This area is mostly occupied by farms and industrial buildings. Generally, the subsidence follows a certain trend in all years with the two major subsidence locations being Yaft Abad (HQHS-HSHT intersection) and south of Shahriar (middle benchmarks of AXAY).

As mentioned earlier, global coordinates for HQSB benchmarks is not available and these benchmarks cannot be modeled in ArcGIS. Land subsidence graphs of these benchmarks are plotted for 2002-2004, 2004-2005, 2002-2005, 2005-2010, and 20022010 in Fig. 9. In this area, during 2002-2004, maximum land subsidence of $560 \mathrm{~mm}$ (280 mm/year) is reported. Through 2004-2005, maximum subsidence rate declines to $130 \mathrm{~mm}$ /year. For 2005-2010, records show a maximum subsidence of $630 \mathrm{~mm}$ (126 mm/year) in this area. In 2010, only seven benchmarks were surveyed. Finally, from 2002 to 2010, the maximum measured subsidence is $1310 \mathrm{~mm}$.

Maximum records of land subsidence in different periods are demonstrated in Fig. 10. This graph shows that the maximum annual subsidence varies from $135 \mathrm{~mm} /$ year (1992-2001) to $249 \mathrm{~mm} /$ year (2001-2003). It is also apparent from the figure that subsidence in south of Yaft Abad and HQHQ-HSHT intersection is occurring faster than other places in most periods.

\section{Groundwater elevation}

Groundwater drawdown is known as the most commonly reported cause of ground subsidence. In this study, groundwater elevation changes are plotted in using ArcGIS for the 

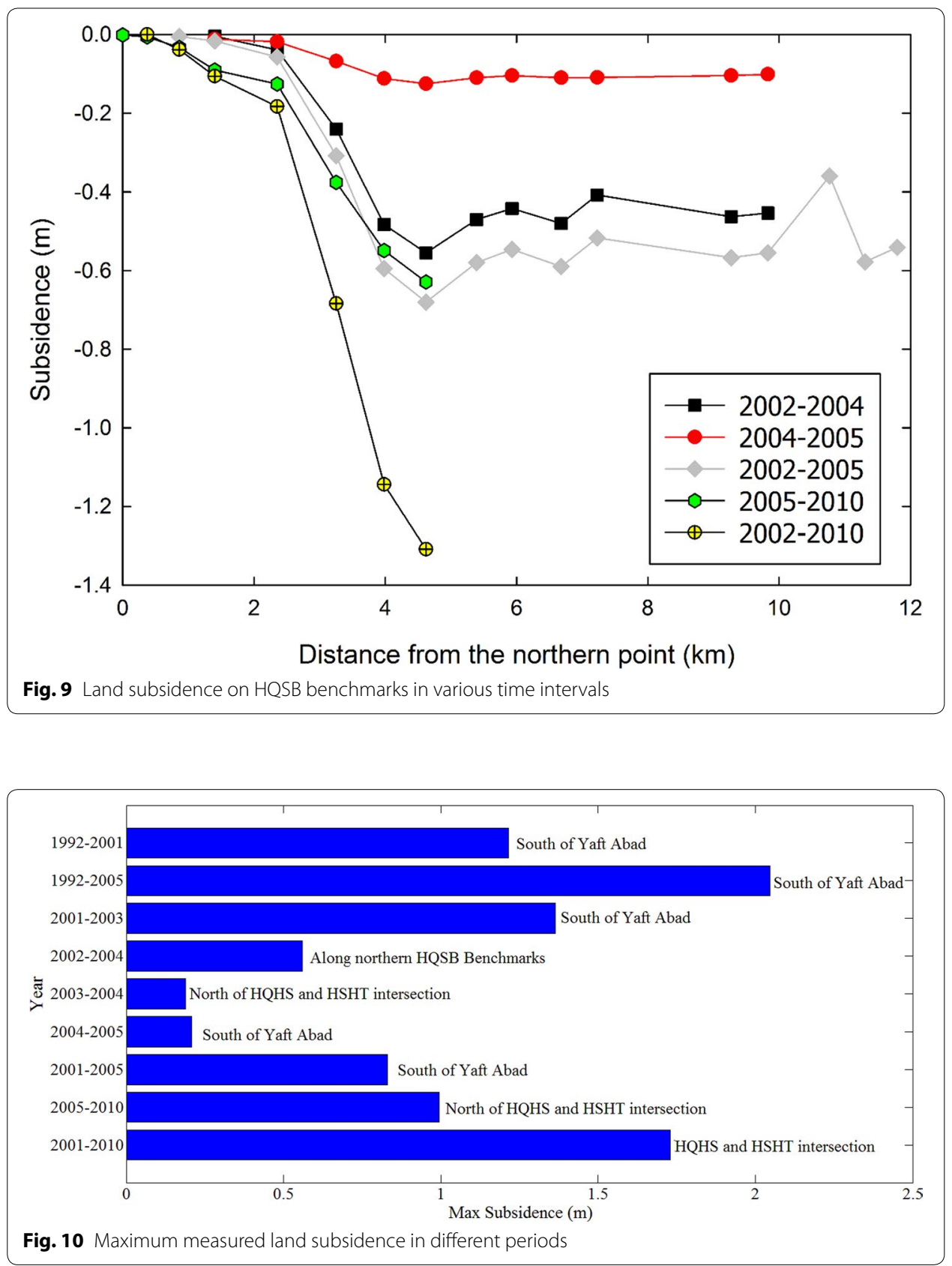

following time intervals: 2002-2003, 2003-2004, 2004-2005, 2002-2005, 2002-2006, 2005-2008, 2008-2010, 2002-2010, and 2002-2011. Figure 11 demonstrates changes in groundwater level for 2005-2008, and changes in groundwater elevation for 20022010 are demonstrated in Fig. 12. Water drawdown is shown in positive and water level increase is shown in negative.

The results reveal that in 2002-2003, considerable changes in water table was not measured, except in some limited places that experienced up to $8 \mathrm{~m}$ change (Fig. 13). As seen in Fig. 14, in 2003-2004, the model follows the same pattern, and water table variations in most places, particularly in areas with high subsidence, are insignificant. 

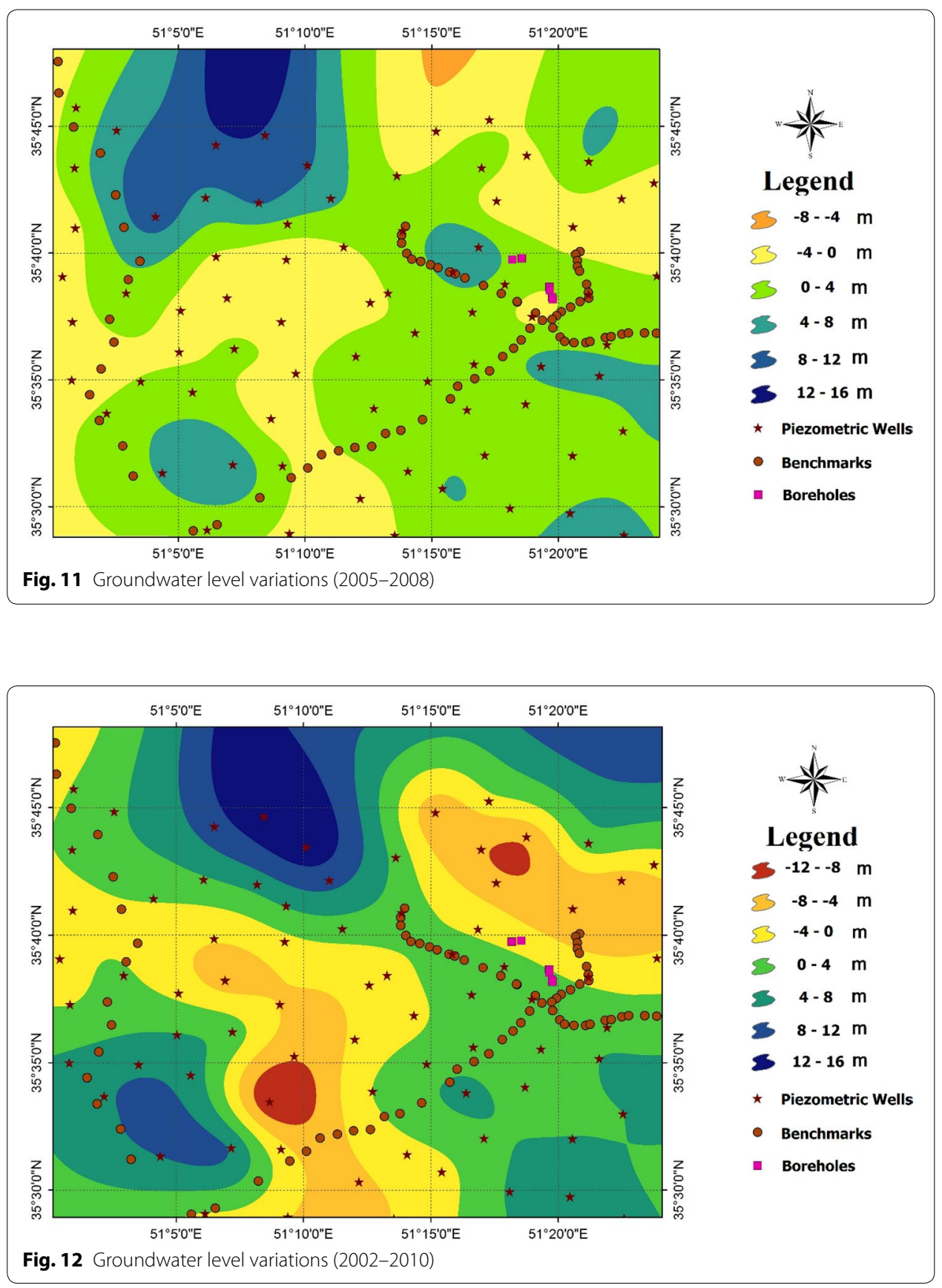

From 2004 to 2005, the same trend continues (Fig. 15), while insignificant increase in groundwater elevation for most of the regions is observed. In addition, water table in 2002-2005 rises no more than $4 \mathrm{~m}$ in main wells, while reducing as much as $4 \mathrm{~m}$ in the remaining wells. Figure 16 illustrates groundwater level variations in this period.

A clear change in groundwater level pattern is noticed after 2005. Water table lowers in the majority of the wells in this period. In 2005-2008, groundwater elevation in most of the wells reduced. As seen in Fig. 11, groundwater level in the majority of wells dropped up to $4 \mathrm{~m}$, and in some few wells it decreased as much as $8 \mathrm{~m}$. Through 2008-2010, 

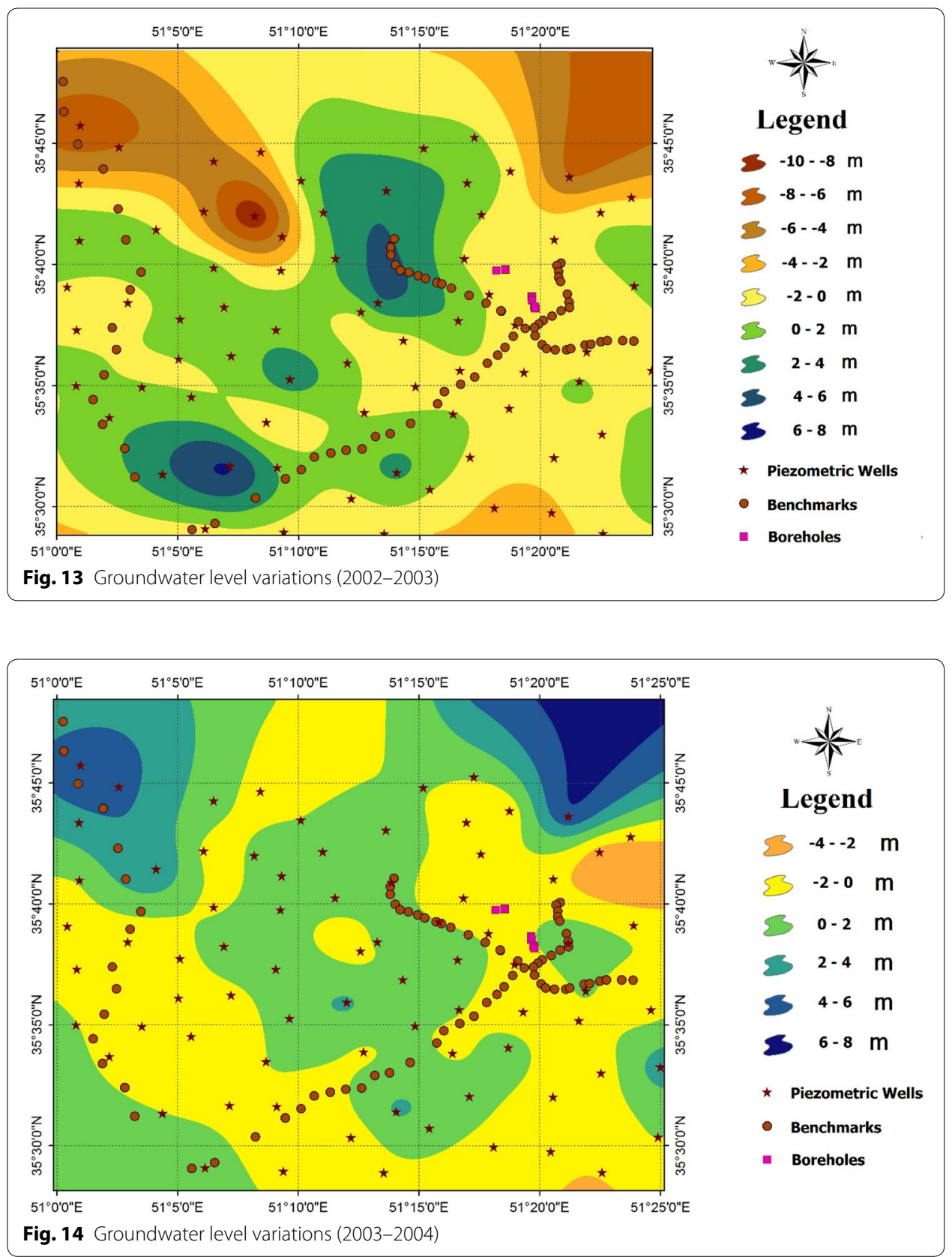

water table drop rate increased, and 2-6 $\mathrm{m}$ decline was recorded in the area between HQHS and HSHT, while it reduced up to $4 \mathrm{~m}$ in the remaining areas of Tehran Plain. On the other hand, groundwater level measurements recorded less than $2 \mathrm{~m}$ increase in the northern area of Shahriar Plain in this period, which is inconsistent with subsidence trend in this area. In conclusion, water table in majority of the locations under quick ground subsidence decreased about $4 \mathrm{~m}$ (Fig. 12), and in the remaining wells, other than the ones in central Shahriar Plain and north of Yaft Abad, drops as high as $8 \mathrm{~m}$ was reported. Groundwater level in south of Shahriar increased up to $12 \mathrm{~m}$. According to the map, water level slightly increased in north of Yaft Abad, which is against the previous trend and is due to lack of water measurement in the wells in yaft Abad for 2010. 

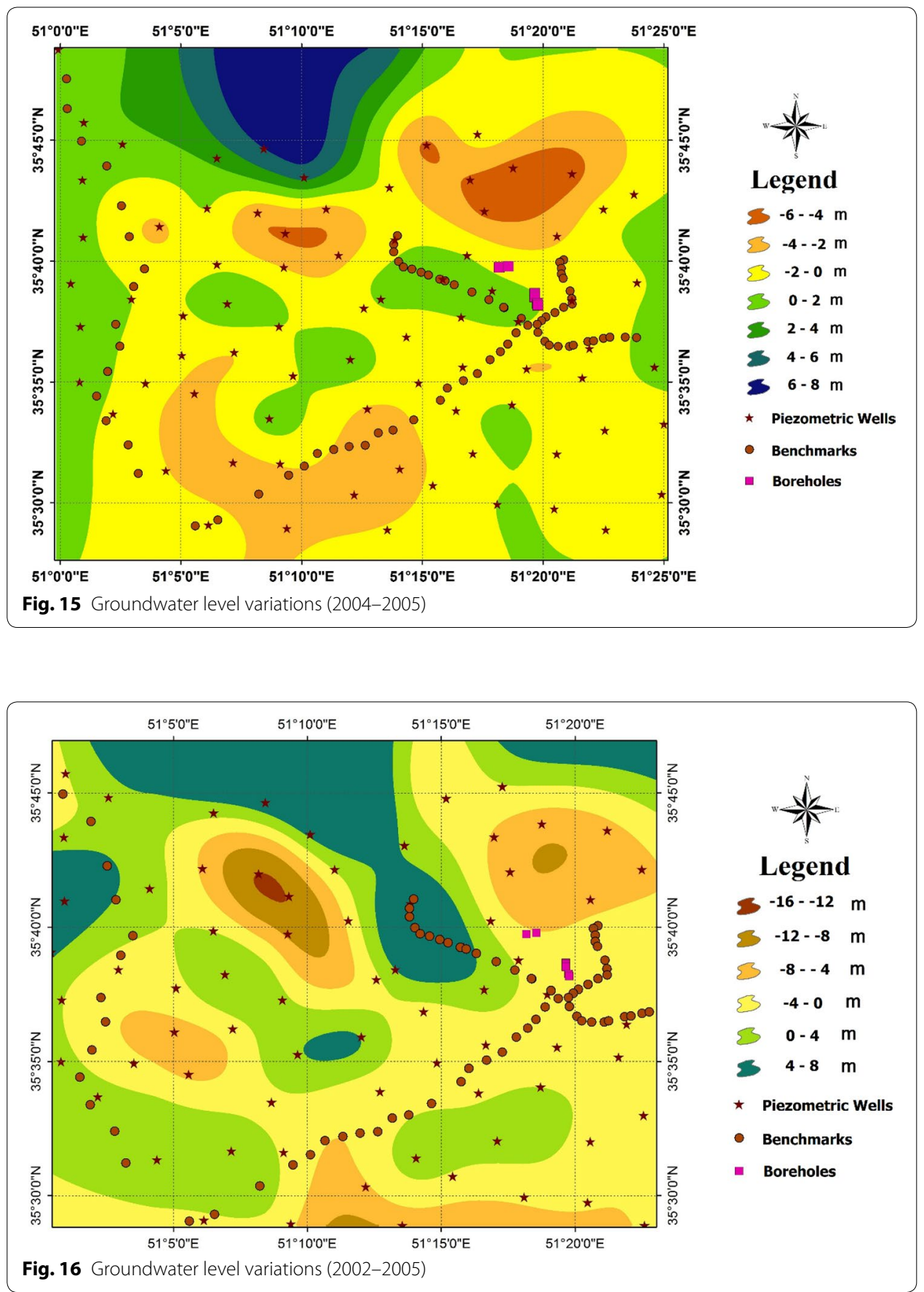

The final studied period is 2002 to 2011 which is more accurate in most regions compared to 2002-2010s map, apart from the intersection of HQHS and HSHT. In this region, Water table was not measured in 2011, but considering the data from other wells, it seems to follow the same pattern as before. In addition, Measurements of a well near Yaft Abad show $9.93 \mathrm{~m}$ decrease in water level in this period which is consistent with previous years and shows that the drawdown shown in Fig. 11 is due to lack of 


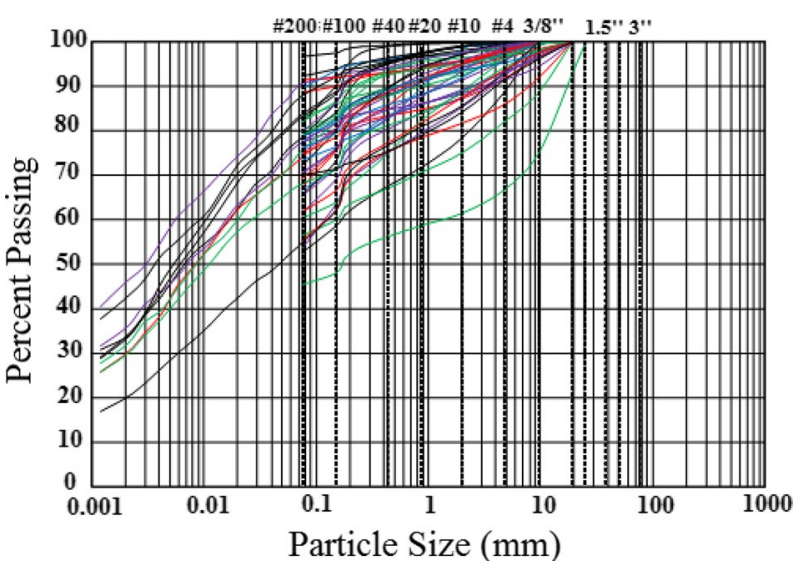

Fig. 17 Grain size distribution test results for a site located in district 18, Tehran

measurements in 2010. According to this map, water level changes have similar trend with a fast increase in drawdown rate.

\section{Soil type}

Soil sampling is performed up to $30-45 \mathrm{~m}$ deep. Grain size distribution tests show that the soil mainly classifies as fine-grained, specifically low plastic clay (CL). Figure 17 illustrates the results from some of these tests. Generally, soil in the northern sections has more granular particles compared to the soil in southern parts. There also is a top layer of fill material with variable thicknesses (up to $10 \mathrm{~m}$ ) available in the area. Clay thickness map is provided in Fig. 18.

\section{Site survey}

Field investigation is a necessity to study land subsidence consequences and damages. It also helps verify the results from desk studies. As southwest Tehran has an old building texture, these studies could not find damages to buildings or roads that can be directly related to subsidence, however, a considerable number of progressing cracks is noticed in different structures in the area. Deep cracks are also observed on many buildings in southern Tehran Plain, specifically Eslamshahr. Furthermore, investigating some of the wells in Tehran shows no signs of wee protrusion, while up to $1 \mathrm{~m}$ casing protrusion is observed in several places in Tehran plain. Figure 19 illustrates a case of well protrusion occurring around Eslamshahr.

Illegal active wells are another problematic issue in draining water supply in Tehran. Some unauthorized well drillings were spotted during the site surveys. Figure 20 illustrates one of these drillings, where more than $50 \mathrm{~m}$ drilling was performed, while the drilling license was issued for a $25-\mathrm{m}$ well.

\section{Results and discussion}

Investigating ground subsidence plots for 2001-2003 period and water table plots during the same period does not imply that water level variations resulted in subsidence for most parts of the city. Subsidence occurred in the main sections of the city even though groundwater level slightly increased. It is important to be considered that lack 

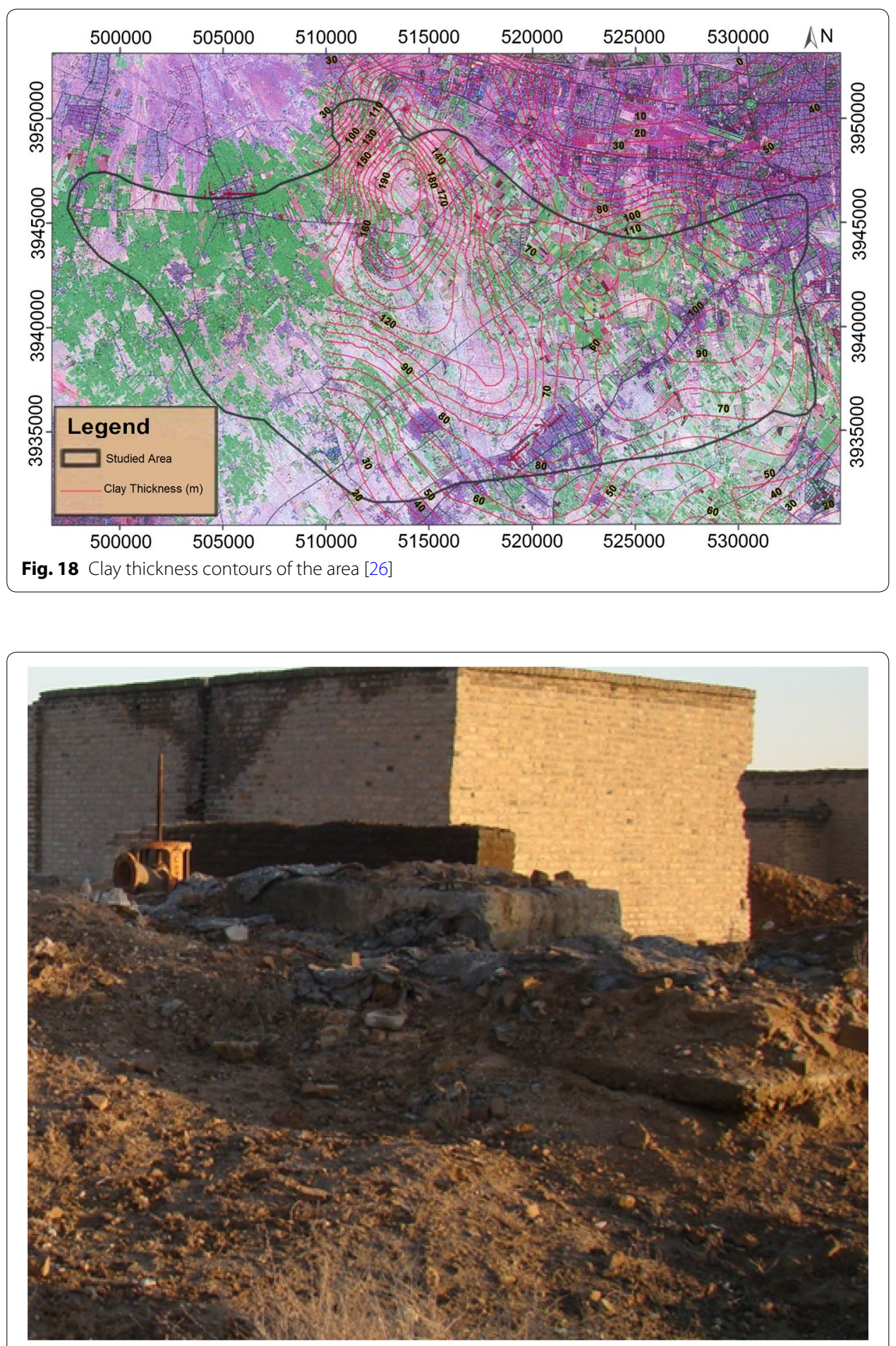

Fig. 19 Well protrusion in agricultural lands in Tehran Plain

of groundwater elevation data prior to 2002 makes it is impossible to conclude if the water table growth was s short term event. Furthermore, secondary compression might be occurring due to previous water level changes. 


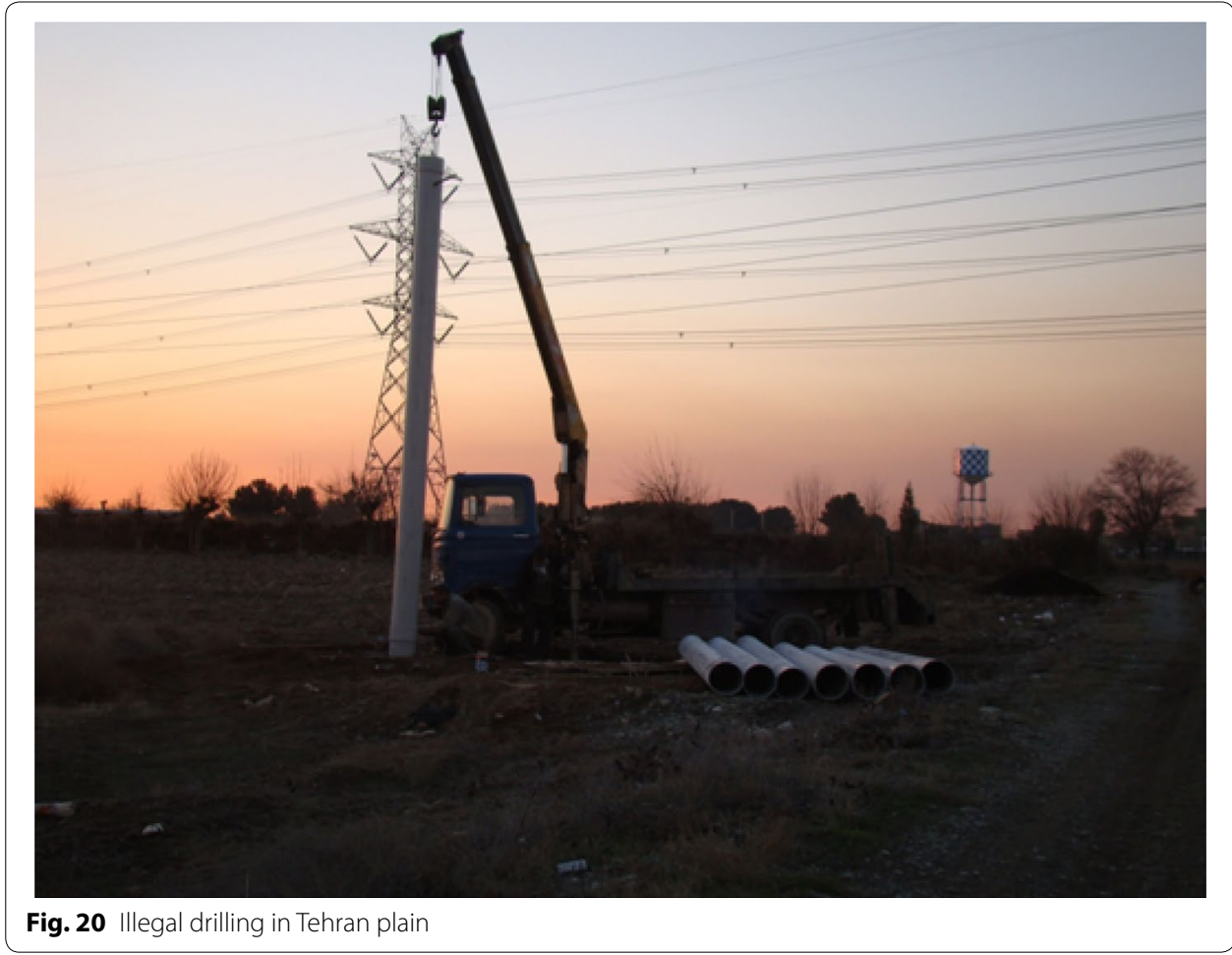

In 2001-2005, northern parts of HSHQ and HSHT experienced 0-0.55 m subsidence that is correspond to up to $8 \mathrm{~m}$ decrease in groundwater. In addition, $4 \mathrm{~m}$ decrease in groundwater elevation led to between 0.2 and $0.4 \mathrm{~m}$ subsidence in Tehran Plain. In general, during 2001-2005, apart from the areas of agricultural land in Shahriar Plain, where groundwater level increased up to $4 \mathrm{~m}$, water table variation can be concluded as the main cause of subsidence. These exception areas will be discussed later in this section.

Comparing water table variations and subsidence in HQHS-HSHT crossing for 20012010 suggests that groundwater extraction cannot be the only reason for subsidence, as water level barely dropped by $4 \mathrm{~m}$ while 1.5 subsidence was measured. However, as discussed before, lack of groundwater elevation for a number of important wells influences the maps in this period. Therefore, considering the $9.93 \mathrm{~m}$ water level reduction measured from 2001 to 2011 and the existence of a thick layer of clay in that area, it can be concluded that water level reduction is the main cause of subsidence in this area. In conclusion, there is an evident general trend of subsidence under water table variations during 2001-2010, except in parts of Shahriar Plain (as discussed before) where groundwater elevation escalated.

Drainage of organic soils is another effective factor in subsidence. As indicated, a considerable portion of land in Tehran and Shariar plains is devoted to agriculture because the area is covered by organic soils. Prior to the wide expansion of cultivation, soil could not undergo any carbon decomposition as it was anaerobic. However, extensive water drainage for cultivation intentions resulted in loss of water content in organic soils which consequently led to oxidation and emission of the existing carbon in form of carbon dioxide. From superimposing the area of subsidence and agricultural lands, it can be 
concluded that ground subsidence is occurring in these places due to organic soil drainage and not water level reduction.

Underground activities are another source of subsidence in southwestern Tehran. Significant number of obsolete qanats exist underneath Tehran (most of which have not been stabilized) resulting in two forms of subsidence; Regional subsidence due to failure of qanats. Figure 21 presents one of the various reported instances of qanat collapse in Tehran. In addition, underground lateral flows and sewage cause subsurface erosion by moving fine-grained soil to the abandoned qanats. The north to south groundwater flow direction and existence of fine-grained materials intensifies this process, leading to faster subsidence rates. Studying groundwater and aqueducts maps reveals that there are many aqueducts in the areas of high settlement which can be effective as a secondary cause of settlement.

Soil excavation is also a source of ground subsidence in southwestern Tehran. There are several brick factories in northern parts of HQHS-HTHX intersection that extensively extract clay, leading to the creation of huge pits. Being several hundred meters wide and up to $20 \mathrm{~m}$ deep, the cavities act as vertical drains that disrupt the aquifer recharge and decrease water level which eventually results in land subsidence. Figure 22 illustrates one of these excavations. Measured ground subsidence for 1992-2010 in this area is $2530 \mathrm{~mm}$.

Dredging granular soils is also a source of subsidence, specifically around Qods (i.e. northern parts of both plains). Similar to the clay pits, cavities generated by dredging affect aqueduct recharge pattern, lower water table, and eventually lead to ground subsidence. Dredging gravel and sand from rivers in the area for use in construction has resulted in removing the permeable layer and consequently lower water penetration and aquifer recharge. Thus, aquifer recharge from Kan River has reduced significantly causing lower groundwater elevation. These extractions often continue upon total removal of

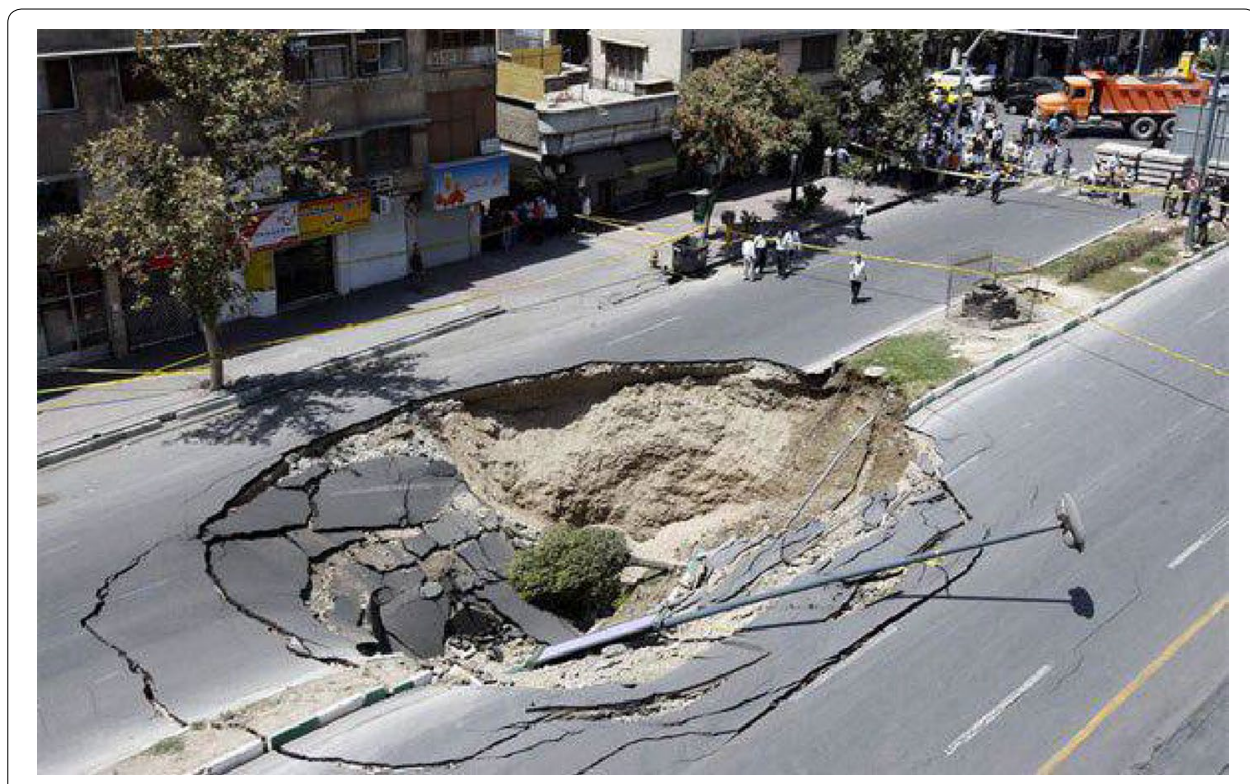

Fig. 21 Collapsed aqueduct near Navab Square, Tehran (east of HSHT) 


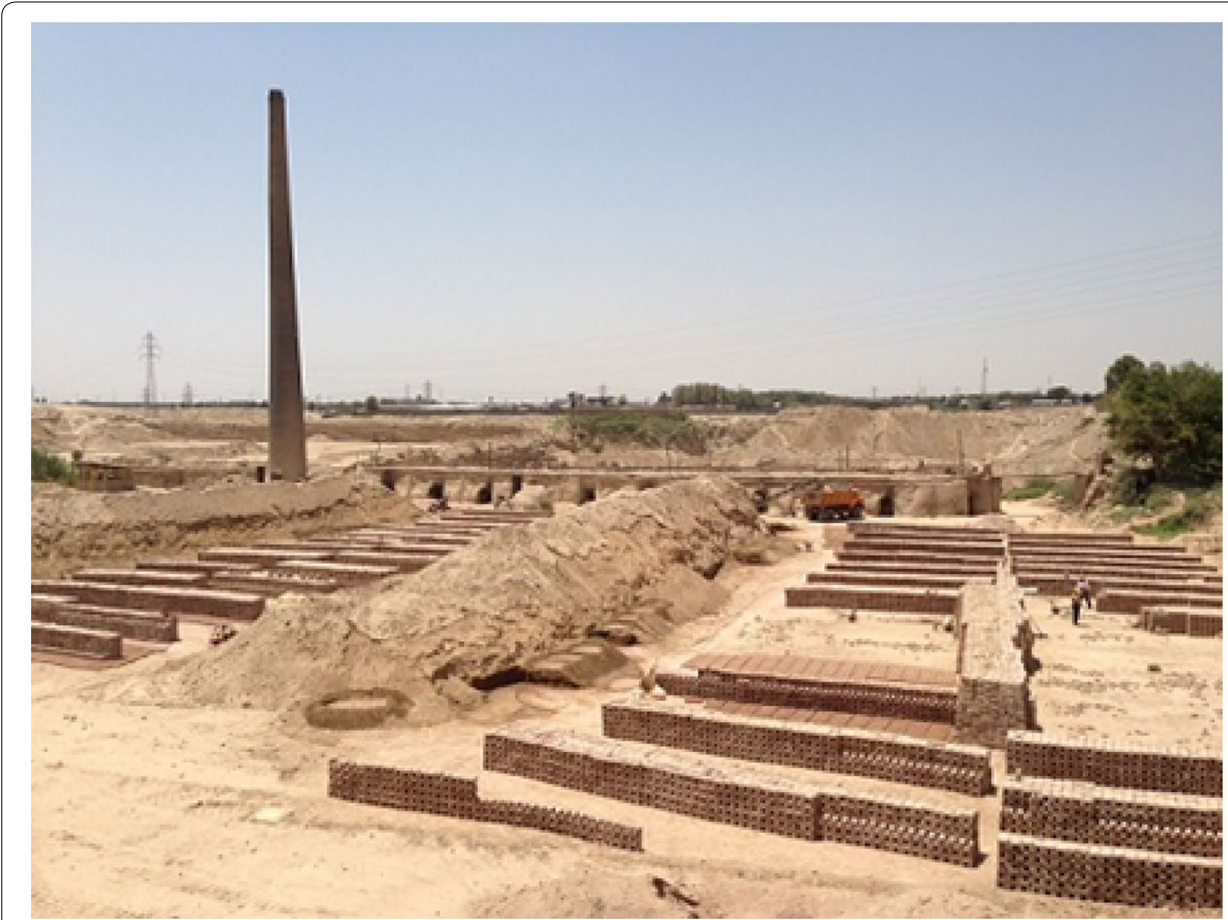

Fig. 22 Clay pit located north of HQHS-HSHT intersection

granular layers and reaching clay layers. Groundwater changes maps reveal that Kan and Karaj rivers have experienced relative water rise, while water table drop was measured in surrounding lands. This reduction proves the decline in aquifer recharge from these rivers.

Existence of clayey soil is a key factor in land subsidence occurrence. Therefore, clay thickness and subsidence maps are studied together. Clay thickness map shows that clay thickness increases from north of HQHS towards its intersection with HSHT, starting from $40 \mathrm{~m}$ in the north. This amount increases to $110 \mathrm{~m}$ in south of Yaft Abad and $90 \mathrm{~m}$ in HQHS-HSHT crossing, which is in agreement with settlement rates. Clay thickness reduces towards east of HTHX and reaches $65 \mathrm{~m}$ at the eastern benchmarks. In addition, clay thickness in the areas along northern HQSB benchmarks, which had highest reported subsidence from 2002 to 2004, is in the 170-m range. Ground subsidence and clay thickness in some places in 1992-2001 and 2001-2010 are shown in Tables 1 and 2. Subsidence measurements support the relationship between clay thickness and subsidence. Finally, as stated earlier, Tehran plain is covered by $\mathrm{C}$ and $\mathrm{D}$ alluviums which are young and prone to consolidation their ongoing consolidation might be partially responsible for land subsidence. It is important to keep in mind that time rate consolidation in thick clay layers (i.e. up to $200 \mathrm{~m}$ ) can take a long time.

Subsidence rate has been increasing in the area and catastrophic events including damages to linear structures, elimination of groundwater storage and flooding will happen if appropriate measures are not taken. Tehran has a significant change in slope from north to south (from 1800 to $950 \mathrm{~m}$ ) and subsidence in southern sections will increase this slope. Restricting groundwater extraction, changing water consumption pattern, 
Table 1 Ground subsidence and clay thickness measurements in some locations (19922001)

\begin{tabular}{lll}
\hline Site & Ground subsidence $(\mathbf{m})$ & Clay thickness $(\mathbf{m})$ \\
\hline North of HQHS & 0.005 & 40 \\
South of Yaft Abad & 1.22 & 95 \\
East of HSHT-HTHX intersection & 0.35 & 55 \\
West of AY-HQHS intersection & 0.06 & 45 \\
AY, north of Eslamshahr & 0.34 & 65 \\
\hline
\end{tabular}

Table 2 Ground Subsidence and clay thickness measurements in some locations (20012010)

\begin{tabular}{lll}
\hline Site & Ground subsidence $(\mathbf{m})$ & Clay thickness $(\mathbf{m})$ \\
\hline North of HQHS & 0 & 40 \\
AY, north of Eslamshahr & 0.51 & 65 \\
AY, Southwest of Eslamshahr & 0.12 & 60 \\
Northwest of HQHS-HSHT interesection & 1.73 & 95 \\
HQSB & 1.31 & 170 \\
\hline
\end{tabular}

improving agriculture methods and artificial recharge are some of the necessary actions that can help preventing the future problems.

\section{Conclusions}

Land subsidence has been affecting $525 \mathrm{~km}^{2}$ of land in Shahriar and Tehran Plains (including the southwestern parts of Tehran) for the past 25 years. Soil in the studied area mainly consists of low plastic clay (CL), and up to $10 \mathrm{~m}$ fill material is reported. Peak measured annual subsidence rate in the research area is $280 \mathrm{~mm}$ /year. The largest reported subsidence during 1992-2010 is $2530 \mathrm{~mm}$ which occurred near brick factories in southwest Tehran. Subsidence rate has been increasing in the area and latest reports indicate that maximum annual rate measurements up to $360 \mathrm{~mm} /$ year.

Current investigation reveals that multiple factors contributed to subsidence in the studied area. Water table drawdown and due to excessive pumping of the wells is the main reason of this phenomenon excluding the central parts of Shahriar Plain. As enough extensive soil consolidation data are not available, it is not possible to make any comments on the time rate consolidation, effects of secondary consolidation, and expected future settlement.

In central Shahriar Plain, oxidation of carbon due to drainage of organic soils is the primary source of subsidence. In this area, largely underlain by agricultural organic soils, groundwater level predominantly increased during the past 20 years. Drainage and depletion of aquifer are also secondary causes of subsidence in the agricultural lands of Tehran plain.

Existence of considerable number of aqueducts in the area escalates subsidence rate through collapse and subsurface erosion. Furthermore, dredging granular soils from rivers as well as clay excavations in south of Tehran for brick factories have accelerated subsidence rate. Highest subsidence measurement is reported close to these clay pits. 
Finally, clay layer thickness is an additional factor that increases the possibility of subsidence occurring. The areas with higher clay thickness experienced higher settlements which can be due to higher compressibility of clays and consolidation of young alluvium in the area.

\section{Authors' contributions}

AP collected the data, derived the model, analyzed the data and wrote the manuscript in consultant with AE. AE supervised the project. Both authors read and approved the final manuscript.

\section{Author details}

${ }^{1}$ Department of Civil and Environmental Engineering, University of Massachusetts, Amherst, USA. ${ }^{2}$ Department of Civil and Environmental Engineering, Amirkabir University of Technology, Tehran, Iran.

\section{Competing interests}

The authors declares that they have no competing interests.

\section{Ethical approval and consent to participate}

Not applicable.

\section{Publisher's Note}

Springer Nature remains neutral with regard to jurisdictional claims in published maps and institutional affiliations.

Received: 18 September 2017 Accepted: 19 December 2017

Published online: 22 December 2017

\section{References}

1. Blourchi M (2013) Young journalist club. http://www.yjc.ir/fa/news/4667664. Accessed Dec 2016

2. Bromley C, Brockbank K, Glynn-Morris T, Rosenberg M, Pender M, O'Sullivan M, Currie S (2013) Geothermal subsidence study at Wairakei-Tauhara, New Zealand. Proc Inst Civ Eng Geotech Eng 166(2):211-223

3. Budhu M, Adiyaman I (2012) Earth fissure formation from groundwater pumping and the influence of a stiff upper cemented layer. Q J Eng Geol Hydrogeol 45(2):197-205

4. Calderhead Al, Therrien R, Rivera A, Martel R, Garfias J (2011) Simulating pumping-induced regional land subsidence with the use of InSAR and field data in the Toluca Valley, Mexico. Adv Water Resour 34(1):83-97

5. Chaussard E, Wdowinski S, Cabral-Cano E, Amelung F (2014) Land subsidence in central Mexico detected by ALOS InSAR time-series. Remote Sens Environ 140:94-106

6. Dehghani M, Valadan Zoej MJ, Entezam I, Mansourian A, Saatchi S (2009) InSAR monitoring of progressive land subsidence in Neyshabour, northeast Iran. Geophys J Int 178(1):47-56

7. Deverel SJ, Rojstaczer S (1996) Subsidence of agricultural lands in the Sacramento-San Joaquin Delta, California: role of aqueous and gaseous carbon fluxes. Water Resour Res 32(8):2359-2367

8. Eslami A, Sekhavatian A (2013) Geotechnical engineering: design, applications and hazards. Tehran Polytechnic Press, Tehran

9. Fang HY, Daniels JL (2006) Introductory geotechnical engineering: an environmental perspective. CRC Press, United States

10. Gabrysch RK (1976) Land-surface subsidence in the Houston-Galveston region, Texas. Proc Anahein Symp 121:16-24

11. Galloway DL, Jones DR, Ingebritsen SE (1999) Land subsidence in the United States, 118 2nd edn. US Geological Survey, Reston

12. Hu RL, Yue ZQ, Wang LU, Wang SJ (2004) Review on current status and challenging issues of land subsidence in China. Eng Geol 76(1):65-77

13. Holzer TL, Johnson Al (1985) Land subsidence caused by ground water withdrawal in urban areas. GeoJournal 11(3):245-255

14. Mahmoudpour M, Khamehchiyan M, Nikudel MR, Ghassemi MR (2016) Numerical simulation and prediction of regional land subsidence caused by groundwater exploitation in the southwest plain of Tehran, Iran. Eng Geol 201:6-28

15. Moghtased-Azar K, Mirzaei A, Nankali HR, Tavakoli F (2012) Investigation of land subsidence due to climate changes in surrounding areas of Urmia Lake (located in northwest of Iran) using wavelet coherence analysis of geodetic measurements and methodological data. In: EGU general assembly conference abstracts, vol 14, p 1485

16. Motagh M, Djamour Y, Walter TR, Wetzel HU, Zschau J, Arabi S (2007) Land subsidence in Mashhad Valley, northeast Iran: results from InSAR, levelling and GPS. Geophys J Int 168(2):518-526

17. Motagh M, Walter TR, Sharifi MA, Fielding E, Schenk A, Anderssohn J, Zschau J (2008) Land subsidence in Iran caused by widespread water reservoir overexploitation. Geophys Res Lett 35:L16403

18. Mousavi SM, Shamsai A, Naggar MHE, Khamehchian M (2001) A GPS-based monitoring program of land subsidence due to groundwater withdrawal in Iran. Can J Civ Eng 28(3):452-464

19. Osmanoğlu B, Dixon TH, Wdowinski S, Cabral-Cano E, Jiang Y (2011) Mexico City subsidence observed with persistent scatterer InSAR. Int J Appl Earth Obs Geoinform 13(1):1-12 
20. Pirouzi A (2013) Analytical and Experimental Study of Land Subsidence in South of Tehran. M.S. thesis, Islamic Azad University, Central Tehran Branch

21. Pirouzi A, Eslami A, Kharaghani S, TavousiTafreshi S (2014) Analytical and experimental study of land subsidence in south western area of Tehran. Vitae Columbia 21(1):233-254

22. Pratt WE, Johnson DW (1926) Local subsidence of the Goose Creek oil field. J Geol 34(7):577-590

23. Rieben EH (1966) Geological observations on alluvial deposits in northern Iran, 9th edn. Geological Survey of Iran, Tehran

24. Rieben EH (1955) The geology of the Teheran plain. Am J Sci 253(11):617-639

25. Rodolfo KS, Siringan FP (2006) Global sea-level rise is recognised, but flooding from anthropogenic land subsidence is ignored around northern Manila Bay, Philippines. Disasters 30(1):118-139

26. Shemshaki A, Blourchi MJ, Ansari F (2005) Preliminary report on Tehran subsidence. Engineering Geology Scientific Report to the Geological Survey of Iran, Tehran

27. TDDMO (2007). Tehran disaster mitigation \& management organization. http://tdmmo.tehran.ir/Default. aspx?tabid=107. Accessed 15 Aug 2016

28. Zhang Y, Xue YQ, Wu JC, Yu J, Wei ZX, Li QF (2008) Land subsidence and earth fissures due to groundwater withdrawal in the Southern Yangtse Delta, China. Environ Geol 55(4):751

Submit your manuscript to a SpringerOpen ${ }^{\circ}$ journal and benefit from:

- Convenient online submission

- Rigorous peer review

- Open access: articles freely available online

- High visibility within the field

- Retaining the copyright to your article

Submit your next manuscript at $\gg$ springeropen.com 